\title{
Association of spiders and lichen on Robben Island, South Africa: a case report
}

\author{
Aeshita Mukherjee ${ }^{1}$, Burkhard Wilske ${ }^{2}$, Rene A. Navarro ${ }^{3}$, \\ Ansie Dippenaar-Schoeman ${ }^{4}$ \& L.G. Underhill ${ }^{3}$ \\ ${ }^{1,3}$ Avian Demography Unit, University of Cape Town, Rondebosch 7701, South Africa. \\ ${ }^{2}$ Blaustein Institutes for Desert Research, Ben-Gurion University of the Negev, Sede Boqer Campus, 84990 Midreshet Ben-Gurion, Israel \\ ${ }^{4}$ Agricultural Research Council, Plant Protection Research Institute, Pretoria 0001, South Africa \\ Email: ${ }^{1}$ aesh2003@yahoo.com
}

Date of publication (online): 26 April 2010 Date of publication (print): 26 April 2010 ISSN $0974-7907$ (online) | 0974-7893 (print)

\section{Editor: Cleofas R. Cervancia}

\section{Manuscript details:}

Ms \# 02295

Received 25 August 2009

Final received 20 January 2010

Finally accepted 17 February 2010

Citation: Mukherjee, A., B. Wilske, R.A. Navarro, A. Dippenaar-Schoeman \& L.G. Underhill (2010). Association of spiders and lichen on Robben Island, South Africa: a case report. Journal of Threatened Taxa 2(4): 815819.

Copyright: (c) Aeshita Mukherjee, Burkhard Wilske, Rene A. Navarro, Ansie DippenaarSchoeman \& L.G. Underhill 2010. Creative Commons Attribution 3.0 Unported License. JoTT allows unrestricted use of this article in any medium for non-profit purposes, reproduction and distribution by providing adequate credit to the authors and the source of publication.

Author Details: See end of this article

Author Contribution: See end of this article

Acknowledgements: Appreciation is extended to the Robben Island Authority, SA for letting us conduct field studies and collect specimens. AM is thankful to the ADU, University of Cape Town for all the support and financial help during the course of study. The Authors were also helped by the reviewers' comments in making the manuscript scientifically more sound.

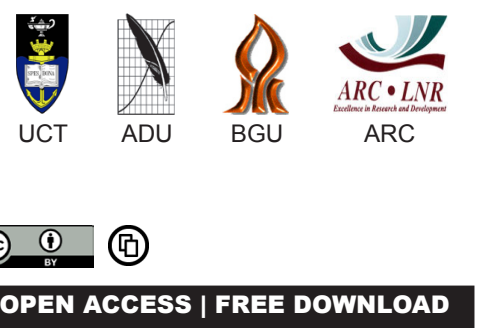

Abstract: The present study is a first record of spider occurrence on Robben Island, South Africa. Some habitats were rich in lichens. As we know, lichens enhance wildlife habitat in less direct ways. The objective of the study was to examine the potential importance of lichens in enriching spider diversity and abundance. A total of 260 spiders (170 from lichens and 90 from bush) were collected following the visual search method over one year. Seasonal trends in overall species richness and abundance indicated that the relative density of spiders was greater in lichens than in bushes. The result suggests that habitat structure, such as branch size and epiphytic lichen abundance, can be an explanation for the greater number of spiders in lichen-rich patches of the island.

Keywords: Robben Island, spiders, lichens, visual search

\section{INTRODUCTION}

With the exception of caribou, whose dependence on lichen is well documented, references to lichens in literature on wildlife are few (Richardson \& Young 1977; Lawrey 1986; Blewitt \& Cooper-Driver 1990). Lichens are less familiar to most researchers than vascular plants; in animal studies they are frequently grouped with other fungi or with mosses. Lichens enhance wildlife habitat in less direct ways. It is worth noting that the given forage may appear to be a rather small percentage of an animal's yearly diet, yet it plays an important strategic role.

Lichens are not a popular food item for animals except for a few. However, Common Greenshield, and other lichens do cover or give shelter to tiny animals, such as water bears, mites, springtails, spiders, insects, and lizards. Some birds are known to use lichens in their nests due to their insulating properties (Richardson \& Young 1977) while some amphibians are known to camouflage perfectly among lichens. Several species of invertebrates live on and among lichens, using them for concealment, shelter or food. Over half of the orders of insects have associations with lichens. There are striking cases of insects mimicking lichens, the most well known being that of the peppered moth (Biston betularia) on lichen-covered tree bark (Richardson 1974). Lichens are a part of many food webs that include invertebrates and their predators. Spiders may prey upon, for example, small lichen-eating arthropods, such as mites or bark lice. Birds, invertebrates and lichens were all found to be functionally connected, and all were impacted by forestry practices (Pettersson et al.1995). Many lichen species contain bitter compounds that may discourage feeding by invertebrates, however, very little is known about the nutritional quality of lichens (Lawrey 1986; Blewitt \& Cooper-Driver 1990).

Other literature shows that many small insects eat lichens exclusively (Hale 1972). According to Gerson \& Seaward (1977) and Seaward (1984), bark lice (Psocoptera) are voracious lichen feeders. Some web spinners 
(Embioptera) eat lichens; they live in silk tunnels, which they construct (Ross 1966; Anon 1970). A noctuid moth, Zanclognatha theralis, in Tennessee, was found to both feed on Usnea trigosa and to look remarkably like the lichen (Sigal 1984).

Many orthopterans mimic lichens. Butterflies and moths (Lepidoptera) have the richest association with lichens (Gerson \& Seaward 1977). Many beetles (Coleoptera) live on or in lichens (Richardson 1974). Some examples of flies (Diptera) are associated with lichens, and a number of studies have found ant (Hymenoptera) nests built underneath lichen mats; Bailey (1970) observed the dispersal of lichen propagules by ants. Some species of termites (Isoptera) in the genus Hospitalitermes feed exclusively on lichens (Kalshoven 1958).

The mites (Acari: Cryptostigmata) live on lichens in great numbers and in varying degrees of dependence on them. These mites play important roles in soil energetic and soil fertility (Seyd \& Seaward 1984). At least one species deposits its eggs in lichens; it secretes a substance which causes the lichen to swell and grow over the eggs, protecting them. Oribatid mites are also the largest category of lichen feeders (Lawrey 1987; Seyd \& Seaward 1984).

Some spiders (Araneae) disguise their webs with lichens, and the giant crab spider of Trinidad constructs nests using lichens of the genus Usnea. Many spiders live in tundra lichens. Except for a few occasional studies no detailed documentation on spiders using lichens as their habitat has been reported. While working on Robben Island, we found it very interesting to note that a few species appeared to be highly dependent on lichens as their primary habitat. It is also worthy to note that spiders are sensitive to microhabitat variation (Foelix 1996). This explains the occurrence of certain species of spiders in selected habitat, governed by particular species of plants (Henschel \& Lubin 1997; Ward \& Lubin 1993) and physical characteristics of the habitat like soil and rocks (Foelix 1996). In addition, low mobility of certain spider species and an innate preference for certain habitats increases the effect of patchiness (Brandt \& Lubin 1998). Understanding the aspects outlined above, the present study aimed at investigating:

(i) seasonal trends in species abundance and the composition in a lichen spider community;

(ii) comparison of adjacent patches of vegetation with regard to spider species composition and abundances.

Throughout the country various monitoring projects were undertaken as part of the South African National Survey of Arachnida. At ARC-Plant Protection Research Institute, Pretoria, for the first time an inventory of the spider families, genera and species known from South Africa were made. It was found that the spider fauna of South Africa is remarkably rich when compared with some other faunas of the world. A total of 67 families of the world's spider families occur in this region represented by 428 genera and about 2900 species. This represents about $9 \%$ of the world's fauna. However, looking at the literature and other published reports we found that no documentation on spiders were reported from Robben Island. Although there exists a booklet describing the wildlife at Robben Island (Crawford \& Dyer 2000) it does not include any information on spiders.

While working on birds at the island, we came across different species of spiders and more interestingly in different microhabitats. We found an appreciable number of jumping spiders along the shoreline. The present study is an attempt to record the occurrence of spiders on Robben Island with special emphasis on those depending on lichens. The study also compared them with the species occurring in the bushes, which are the closest microhabitat adjacent to the lichens. The paper is a part of the arachnid survey of the shorelines of South Africa, which is a first of its kind. To the best of our knowledge, this paper presents the first record from Africa of spiders occurence related with lichens.

\section{METHODS}

\section{Study Area}

The study was conducted on Robben Island, $\left(33.8^{\circ} \mathrm{S}\right.$, $18.36^{\circ} \mathrm{E}$ ), a world heritage site, South Africa. Robben Island is roughly oval in shape; $3.3 \mathrm{~km}$ long north south, and $1.9 \mathrm{~km}$ wide, with an area of $5.07 \mathrm{~km}^{2}$ and is the largest in a string of islands, which lie along the southwestern coast of Africa. The island is relatively flat, rising to a height of $30 \mathrm{~m}$ above sea level, as a result of an ancient erosion event. It is $7 \mathrm{~km}$ from the nearest mainland (Cape Town). Winters are cool and rainy, whereas summers are hot and dry making a very distinct climate on the island. The indigenous vegetation is quite similar to that of the mainland. The island makes a unique habitat, having both indigenous and exotic species of flora and fauna. For recreation and for game, certain antelopes, mammals and birds were introduced to the island. The island harbours over 7000 penguins and several other sea birds and seals. The government, during the apartheid, introduced ungulates and some other animals now found on the island, as a resource for entertainment. The island has a distinct habitat of grassland, and a rocky shore. About 100 human habitations exist on the island, which makes a different surrounding for the occurrence of spiders. The island was mainly used until 1994 as the political prison during the apartheid era. As a result the island was never surveyed for any scientific purposes.

\section{Survey}

The whole island has very specific vegetation patches and so we took them separately to monitor the spider abundance and richness. About 500m from the 
seashore the lichens grow both on the rocks and on the semi dry branches. About $100 \mathrm{~m}$ adjacent to it, bushes of Australian acacia occured void of lichens. Visual search was employed to collect the spiders occurring both on the bushes and on the lichens. Every month collection was done for $2 \mathrm{hrs}$ (searching 20 random points) at each habitat for three consecutive days. We also did pitfall trapping, but the data obtained has not been used in this paper as they may mislead by mixing of species from other microhabitats.

\section{Data analysis}

Spiders collected were sorted as to species (if adult) or to genus or family if juvenile. Species identifications were confirmed by Prof. Dr. Ansie Dippenaar-Schoeman (ARC, Plant protection, Pretoria) and specimens were deposited in the National Collection for reference.

We analysed the monthly data from October 2003 to September 2004. Spider data were analysed for seasonal trends in overall species richness and abundance and in the trends for different species. We compared the two trapping sites with regard to spider abundance. Similarity indices were calculated to compare the species between seasons and between the two sites

\section{RESULTS}

Over the year, 260 spiders (170 from lichens and 90 from bushes) were collected. Winter and early spring had lower numbers of spiders than late spring, summer and autumn. April showed a distinct peak in numbers, followed by stable numbers throughout summer and a smaller increase in the autumn as a general trend. In lichens the numbers were significantly high during autumn while in the bushes the numbers were high in summer.

The relative density of spiders was greater in lichens over the 12 monthly samples. Overall, more spiders were trapped in lichen (median, range: $41.5,6-109$ ) than in bushes (22.5, 1-74; Wilcoxon signed ranks test, $z=$ 2.275, $p=0.023$ ). After square root transformation to normalize the data, we performed repeated measures analysis on the total number of spiders, with seasons repeated measures and site as a factor. The effect of season (within subjects) was significant $\left(F_{3,12}=3.578, p\right.$ $=0.047$ ), but none of the sites $\left(F_{1,4}=1.04, p=0.37\right)$ nor the interaction between site and season $\left(F_{3,12}=0.643, p\right.$ $=0.6$ ) were significant.

In the two sites combined, we recorded 15 species, of which four were identified to species level. In lichens there were ten species, while in bushes eight species were recorded (Table1). Only three species were common to both the habitats (Caerostris, Neoscona subfusca and Vidole capensis). Aridna sp. of the family Segestridae was found only on lichen on the whole island. In lichens the most common species was Neoscona subfusca
Table 1. Comparative abundance of spiders in two microhabitat of Robben Island

\begin{tabular}{|c|c|c|c|}
\hline \multirow[b]{2}{*}{ Family } & \multirow[b]{2}{*}{ Genus/species } & \multicolumn{2}{|c|}{ Abundance in } \\
\hline & & Bush & Lichen \\
\hline \multirow[t]{2}{*}{ Araneidae } & $\begin{array}{l}\text { Neoscona subfusca C.L. } \\
\text { Koch, } 1837\end{array}$ & 10 & 85 \\
\hline & Caerostris & 5 & 45 \\
\hline Caponiidae & Caponia sp. & 5 & \\
\hline Gnaphosidae & Trephopoda sp. & & 5 \\
\hline Linyphidae & Linyphidae sp. 1 & & 5 \\
\hline Philodromidae & $\begin{array}{l}\text { Suemus punctatus } \\
\text { (Lawrance, 1938) }\end{array}$ & & 5 \\
\hline Pholcidae & Smeringopus & & 5 \\
\hline Phyxelididae & $\begin{array}{l}\text { Vidole capensis (Pocock, } \\
1900)\end{array}$ & 10 & 5 \\
\hline \multirow[t]{3}{*}{ Salticidae } & $\begin{array}{l}\text { Menemerus bivittatus } \\
\text { (Dufour, 1831) }\end{array}$ & 10 & \\
\hline & Salticidae sp.2 & & 5 \\
\hline & Menemerus sp.2 & & 5 \\
\hline Segestridae & Ariadna sp. & & 5 \\
\hline \multirow[t]{3}{*}{ Theridiidae } & Theridion sp.1 & 15 & \\
\hline & Steatoda & 20 & \\
\hline & Steatoda sp.1 & 15 & \\
\hline Total & & 90 & 170 \\
\hline
\end{tabular}

(family Araneidae, $85 \mathrm{indv}$.) while in bushes, Steatoda and Theridion sp. were highest in number (20 and 15, family Theridiidae). Only three species were common to both the habitats (Caerostris, Neoscona subfusca and Vidole capensis). The overall species diversity was similar in both the sites (1.85 in lichen and 1.67 in bush).

\section{Plant density}

The plant density at both locations was similar, (site lichen 3.95 and site bush 3.61; Wilcoxon test, $z=-0.364$, $n 1 \& n 2=4, p=0.715$ ). Site lichen had four species of shrubs and site bush had three shrub species. Australian acacia constituted $87 \%$ of the shrubs in site lichen and $89 \%$ in bushes. The shrub height and diameter was similar (Average diameter ranged from $51 \mathrm{~cm}$ to $59 \mathrm{~cm}$, and the height varied from $26 \mathrm{~cm}$ to $32 \mathrm{~cm}$ ).

\section{DISCUSSION}

The difference in the site characteristics and its influence on species richness seemed difficult to explain, as the two sites are apart by approximately $100 \mathrm{~m}$. However, a possible suggestion is vegetation composition, which makes one habitat more suitable than the other one. Host plant size is probably a factor, which accounts for the species abundance, as the larger shrubs generally lead to an increase in species diversity of resource available (Lawton 1983, 1986). It is also known that the phytophagous fauna increases 
with a plant's structural complexity (Strong et al. 1984), and a distinct positive association exists between beetle diversity and plant composition (Southwood et al. 1979). Further it is seen in the study that the species composition shows a specific trend across the seasons. This could be due to the preference of the species for a particular host vegetation. Most studies on spiders showed that there is a positive association between species richness of orb builders and plant canopy complexity (Stratton et al. 1979; Hatley \& MacMohan 1980; Greenstone 1984). A similar pattern was found among the hunting spiders (Duffey 1962 a,b; Uetz 1991). Although some species show little food discrimination, other species show marked food and habitat preference (Thornton 1985). The availability of food across the seasons may be one of the factors influencing the change in the species composition. On the other hand many spider species are highly mobile and some move long distances, while some spiders are not fixed with the same plant structure (Forster \& Forster 1999). While it is assumed that increased habitat complexity would provide more environmental niches and foraging opportunities, the results indicate that this is not the case for all organisms. Thus, the effects of habitat complexity cannot be generalized. Even within spider communities ground dwellers may differ in their preference for habitat complexity versus tree dwelling species suggesting the need to group species by functional groups (Lassau \& Hochuli 2004). There could be a tremendous effect of season and the age of the trees bearing lichens to predict spider richness. For example, the spider richness was correlated and varied greatly with season and weather in a forested landscape in Sweden (Gunnarsson et al. 2004).

In the present study, only those specimen were considered that were found in the habitats using visual search. So it is more likely that only those were collected that walked/webbed on the foliage. Therefore the studies do not represent the whole community of spiders and other invertebrates. However, spiders were sampled from all possible patches within the habitat, to get an overview in an ongoing study. In an ongoing study we are also collecting spiders and other invertebrates from other habitats to add to this preliminary survey. This study in Africa is the first of its kind representing spider communities on an island. It is suggested that habitat structure (branch size and epiphytic lichen abundance) could be an explanation for the greater number of spiders in lichen-rich patches of the island. The study also emphasises the usage of lichen as a very potential habitat, which has never been documented earlier or studied in detail in South Africa and we hope such studies will be taken up in the future.

\section{REFERENCES}

Anon. (1970). The Insects of Australia. University Press, Melbourne, 565pp.

Bailey, R.H. (1970). Animals and the dispersal of soredia from Lecanora conizaeoides Nyl. ex Cromb. Lichenologist 4: 256.

Blewitt, M.R. \& G.A. Cooper-Driver (1990). The effects of lichen extracts on feeding by gypsy moths (Lymantria dispar). The Bryologist 93(2): 220-221.

Brandt, Y. \& Y. Lubin (1998). An experimental manipulation of vegetation structure: consequences of desert spiders. Israel Journal of Zoology 44: 201-216.

Crawford, R. \& B. Dyer (2000). Wildlife of Robben Island. Underhill, L.G. (ed.), Avian Demography unit, UCT, South Africa, 32pp.

Duffey, E. (1962a). A population study of spiders in limestone grassland: description of study area, sampling methods and study area characteristics Journal of Animal Ecology 31: 571-599.

Duffey, E. (1962b). A population study of spiders in limestone grassland, the field layer fauna Oikos 13: 15-34.

Foelix, R.F. (1996). Biology of Spiders (2 ${ }^{\text {nd }}$ edition) Oxford university Press, Oxford.

Froster, R.R. \& L.M. Froster (1999). New Zealand Spiders and their Worldwide Kin. Dunedin University of Otago Press, 270pp.

Gerson, U. \& M.R.D. Seaward (1977). Lichen-invertebrate associations, pp.69-119. In: Seaward, M.R.D. (ed.). Lichen Ecology. Academic Press, London.

Greenstone, M.H. (1984). Determinants of web spider species diversity: vegetation structural diversity vs prey availability Oecologia 62: 299-304.

Gunnarsson, B., M. Hake \& S. Hultengren (2004). A functional relationship between species richness of spiders and lichens in spruce. Biodiversity and Conservation 13: 685-693.

Hatley, C.L. \& J.A. MacMohan (1980). Spider community organization: seasonal variation and the role of vegetation architecture. Environmental Entomology 9: 632-639.

Henschel, J.R. \& Y. Lubin (1997). A test of habitat selection at two spatial scales in a sit and wait predator: a web spider in the Namib desert dunes. Journal of Animal Ecology 66: 401-413.

Kalshoven, L.G.E. (1958). Observations on the black termites, Hospitalitermes sp., of Java and Sumatra. Insectes Society 5: $9-30$.

Lassau S. A. \& D.F. Hochuli (2004). Effects of habitat complexity on ant assemblages. Ecography 27: 157-164.

Lawrey, J.D. (1986). Biological role of lichen substances. The Bryologist 89(2): 111-122.

Lawrey, J.D. (1987). Nutritional ecology of lichen/moss arthropods, pp.209-233. In: Slansky, F. \& J.G. Rodriquez (eds.). Nutritional Ecology of Insects, Mites, Spiders, and Related Invertebrates. John Wiley \& Sons, 1032pp.

Lawton, J.H. (1983). Plant architecture and diversity of phytophagous insects. Annual Review of Entomology 28: 23- 39.

Lawton, J.H. (1986). Surface availability and insect community structure: The effect of architecture and fractal dimension of plants, pp.317-331. In: Junniper, B. \& T.R. Southwood (eds.). Insects and the Plant Surface. Edward Arnold, London, 360pp.

Pettersson, R.B., J.P. Ball, K.E. Renhorn, P.A. Esseen \& K. Sjoberg (1995). Invertebrate communities in boreal forest canopies as influenced by forestry and lichens with implications for passerine birds. Biological Conservation 74: 57-63.

Richardson, D.H.S. (1974). The Vanishing Lichens. Hafner Press, New York, 231pp. 
Richardson, D.H.S. \& C.M. Young (1977). Lichens and vertebrates, pp.121-144. In Seaward, M.R.D. (ed.). Lichen Ecology. Academic Press, London, 550pp.

Ross, E.S. (1966). A new species of Embioptera from the Galapagos Islands. Proceedings of the California Academy of Sciences $4^{\text {th }}$ series, XXXIV(12): 499-504.

Seaward, M.R.D. (1984). Contribution of lichens to ecosystems, pp.107-129. In: Galun, M. (ed.). CRD Handbook of Lichenology, Vol.II. CRC Press, Inc., Boca Raton, Florida.

Sigal, L.L. (1984). Of lichens and lepidopterons. The Bryologist 87(1): 66-68.

Southwood, T.R.E., V.K. Brown \& P.M. Reader (1979). The relationship of plant and insect diversities in succession. Biological Journal of Linnaean Society 12: 327348.

Stratton, G.E., G.W. Utez \& D.G. Dillery (1979). A comparision of the spiders of three coniferous tree species. Journal of Arachnology 6: 219-226.

Strong, D.R., J.H. Lawton \& T.R.E. Southwood (1984). Insects on Plants; community pattern and mechanisms Oxford, Blackwell Scientific Publications.

Thornton, I.W.B. (1985). The geographical and ecological distribution of arborea Psocoptera. Annual Review of Entomology 30:175-196.

Uetz, G.W. (1991). Habitat structure and spider foraging, pp.325-348. In: Bell, S.S., E.D. McCoy \& H.R. Mushinsky (eds.). Habitat Structure: The Physical Arrangements of Objects in Space. Chapman and Hall, London, 438pp.

Ward, D. \& Y. Lubin (1993). Habitat selection and life history of a desert spider Stegodyphus lineatus (Eresidae). Journal of Animal Ecology 62: 353-363.
Author Details: Dr. Aeshita Mukherjee is an ecologist and was a postdoctoral fellow at the University of Cape Town, South Africa.

DR. BURKHARD WILSKE is an ecophysiologist, botanist having expertise in VOC and carbon budgeting. $\mathrm{He}$ is presently a postdoctoral fellow at the Bio-Geosciences Institute, University of Calgary, Canada.

RENE A. NAVARRo is an ecologist having expertise in satellite data analysis and, presently working on spiders at the University of Cape Town in South Africa.

Prof. Ansie DippenaAr-Schoeman is an arachnologist and a well-known taxonomist, presently a scientist at ARC, Plant protection, Pretoria, SA.

PROF. L.G. UNDERHILL is a statistician, expertise in employing statistics to ecology. Presently he is the Director of Avian Demography Unit, at the University of Cape Town, South Africa.

Author Contribution: The first author designed the study, collected data, compiled and analyzed the data and wrote this manuscript, while the second author's input was interpretation of result, literature search and helping in analysis. The Third author contributed his time in conducting the field surveys. The fourth author helped in species identification. The fifth author helped in all the statistical analysis in the paper and was the project-in-charge. 